Article

\title{
Probing the Structural Determinants of Amino Acid Recognition: X-Ray Studies of Crystalline Ditopic Host-Guest Complexes of the Positively Charged Amino Acids, Arg, Lys, and His with a Cavitand Molecule
}

\author{
Giovanna Brancatelli ${ }^{1}$, Enrico Dalcanale ${ }^{2}\left(\mathbb{D}\right.$, Roberta Pinalli ${ }^{2, *(1)}$ and Silvano Geremia ${ }^{1, *(D)}$ \\ 1 Centre of Excellence in Biocrystallography, Department of Chemical and Pharmaceutical Sciences, \\ University of Trieste, 34127 Trieste, Italy; giovanna_brancatelli@hotmail.com \\ 2 Department of Chemistry, Life Sciences and Environmental Sustainability, University of Parma, and INSTM, \\ UdR Parma, Parco Area delle Scienze 17/A, 43124 Parma, Italy; enrico.dalcanale@unipr.it \\ * Correspondence: roberta.pinalli@unipr.it (R.P.); sgeremia@units.it (S.G.); Tel.: +39-0521-905464 (R.P.); \\ +39-040-558-3936 (S.G.)
}

Academic Editors: Maria Elizabeth Tiritan, Madalena Pinto and Carla Sofia Garcia Fernandes Received: 19 November 2018; Accepted: 18 December 2018; Published: 19 December 2018

\begin{abstract}
Crystallization of tetraphosphonate cavitand Tiiii $\left[\mathrm{H}, \mathrm{CH}_{3}, \mathrm{CH}_{3}\right]$ in the presence of positively charged amino acids, namely arginine, lysine, or histidine, afforded host-guest complex structures. The X-ray structure determination revealed that in all three structures, the fully protonated form of the amino acid is ditopically complexed by two tetraphosphonate cavitand molecules. Guanidinium, ammonium, and imidazolium cationic groups of the amino acid side chain are hosted in the cavity of a phosphonate receptor, and are held in place by specific hydrogen bonding interactions with the $\mathrm{P}=\mathrm{O}$ groups of the cavitand molecule. In all three structures, the positively charged $\alpha$-ammonium groups form $\mathrm{H}$-bonds with the $\mathrm{P}=\mathrm{O}$ groups, and with a water molecule hosted in the cavity of a second tetraphosphonate molecule. Furthermore, water-assisted dimerization was observed for the cavitand/histidine ditopic complex. In this 4:2 supramolecular complex, a bridged water molecule is held by two carboxylic acid groups of the dimerized amino acid. The structural information obtained on the geometrical constrains necessary for the possible encapsulation of the amino acids are important for the rational design of devices for analytical and medical applications.
\end{abstract}

Keywords: amino acid; phosphonate cavitand; molecular recognition; X-ray structure; host-guest chemistry; lysine; arginine; histidine

\section{Introduction}

L-Arginine (Arg), L-lysine (Lys), and L-histidine (His) belong to the class of 20 proteinogenic amino acids. Arg is classified as a conditionally essential amino acid for adults [1], and it serves as a precursor for methylguanidoacetic acid (creatine), which plays an essential role in the energy metabolism of muscle, nerve, and testis, and accounts for Arg catabolism of (4-aminobutyl)guanidine (agmatine) by decarboxylation. Arg is involved as a substrate in the urea cycle, and in nitric oxide production, the removal of ammonia from the body, cell division, and functioning of the immune system [2]. Lysine is an essential amino acid that plays an important role in the solvation, structure, and activity of proteins [3]. Arg and Lys are mostly exposed to the globular protein surface, and they are involved in the electrostatic interactions in protein-protein and protein-DNA complexes. Furthermore, through salt bridge formation with the complementary Glu and Asp residues, they contribute to the 
protein stability [4,5]. Arg and Lys side chain methylations are fundamental in post-translational modifications of histones, essential in epigenetic regulation. Methylations occur primarily at Lys and Arg residues on the histone backbone [6], affecting transcriptional regulation [7], assembly of heterochromatin, and cell cycle progression [8].

His is a conditionally essential amino acid, and plays an important role in the growth and repair of tissues, in the control of the metal elements transmission in biological bases [9], and in protein interactions [10]. Histidine is present in the naturally occurring histidine-rich protein II (HRP2), a common target for rapid diagnostic tests for malaria [11]

The unique structures of the three proteinogenic basic amino acids, Arg, Lys, and His, having long and positively charged side chains, make them interesting targets among the twenty amino acids for the molecular recognition of a specific side chain in a peptide $[10,12]$.

In the literature, there are many examples reporting the use of synthetic macrocycles for Arg and Lys amino acid recognition [12-15], while the use of molecular receptors for histidine recognition is less explored [16].

Cavitands are a class of abiotic macromolecular receptors based on a resorcinarene scaffold having enforced cavities of molecular dimensions [17,18]. In the design of cavitands, the choice of the bridging groups connecting the phenolic hydroxyls of the resorcinarene scaffold determines shape, rigidity, dimensions, and complexation properties of the resulting cavity [19]. The selection can be made based on the particular class of analytes to be detected. Besides shape complementary, the selective recognition of a guest by a cavitand host requires the presence of specific weak interactions such as hydrogen bonding [20], $\pi-\pi$ stacking [21], $\mathrm{CH}-\pi$ [22], and cation- $\pi$ interactions [23]. The degree of sophistication achieved in controlling weak host-guest interactions in cavitands is such that it allows the rational design of synthetic receptors according to the analyte to be detected. The different functionalization of the cavity upper rim leads to the synthesis of cavitands presenting remarkable molecular recognition properties towards different guests, like aromatic and halogenated hydrocarbons [24-28], short chain alcohols [29,30], and N-methylammonium salts [31]. The ability of the cavitands to selectively recognize analytes can be exploited in solution [31], and at the gas-solid $[25,26]$ and solid-liquid interface $[28,30]$. In particular, tetraphosphonate cavitands, named Tiiii [32], were successfully employed in the molecular recognition of biological relevant $N$-methyl ammonium salts, like sarcosine in urine $[33,34]$. The origin of Tiiii selectivity toward these species can be attributed to the presence of three different interaction modes: (i) $\mathrm{N}^{+} \ldots \mathrm{O}=\mathrm{P}$ cation-dipole interactions; (ii) cation- $\pi$ interactions of the ${ }^{+} \mathrm{N}-\mathrm{CH}_{3}$ group with the $\pi$ basic cavity; and (iii) two simultaneous hydrogen bonds between two adjacent $\mathrm{P}=\mathrm{O}$ bridges and the two nitrogen protons. Recently, the ability of Tiiii in selectively complex different amino acids, both in solution and in the solid state, was demonstrated [35]. The work focused on the interaction of Tiiii with the ammonium/N-methyl ammonium group of 13 amino acids, neglecting the complexation of amino acids with biologically relevant substituents like guanidinium (Arg) and imidazole (His). These side chains are relevant targets for protein camouflage, since molecular receptors that recognize protein surfaces are important tools for recognition and activity modulation of proteins [36-40]. Sulfonatocalix[4]arene and cucurbiturils turned out to be the preferred synthetic receptors for protein surface recognition [41-43].

A recent work of Paton and co-workers describes the cation- $\pi$ interactions of neutral aromatic ligands, using benzene as an archetype, with the cationic amino acid residues Arg and Lys via ab initio calculations, symmetry-adapted perturbation theory (SAPT), and a systematic meta-analysis of all available Protein Data Bank (PDB) X-ray structures [44]. The Lys-arene interaction is predicted to be weakened by polar surroundings to the point that it has a negligible effect on an aromatic ligand binding mode. By contrast, the cation $-\pi$ interaction made by Arg residues with aromatic ligands is more robust to changes in the surrounding environment.

Here, we report the crystal structures of three complexes between the Tiiii cavitand as host and Arg, Lys, and His as guests. The purpose of the study is to determine which are the interactions 
responsible for amino acid recognition in the three cases, and to identify the role of the amino acids side chain in the complexation event.

\section{Results and Discussion}

Within a systematic crystallization program to assess the complexation properties of tetraphosphonate cavitands towards amino acids in the solid state [36], we obtained crystals of the fully protonated form of proteinogenic positively charged amino acids, such as Arg, Lys, and His. Crystallization trials were performed using the vapor diffusion method with sitting drops technique in Linbro multi-well plates containing trifluoroethanol (TFE) as solvent and PEG300 as precipitant (see Material and Methods). Within the class of tetraphosphonate cavitand, $\operatorname{Tiiii}\left[\mathrm{H}, \mathrm{CH}_{3}, \mathrm{CH}_{3}\right]$, a compact synthetic receptor without substituents at its lower rim (Scheme 1), was chosen for its great tendency to crystallize. Then, accurate crystal structures of the Arg, Lys, and His amino acids complexed with the tetraphosphonate cavitand were determined by single crystal X-ray diffraction using synchrotron radiation as $\mathrm{X}$-ray source, with crystals quenched at cryogenic temperatures (see Material and Methods).

a)

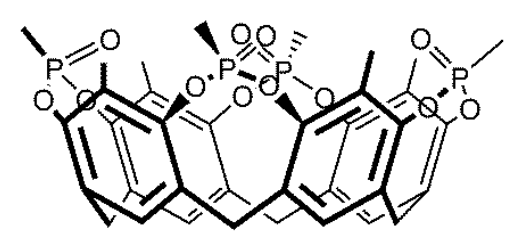

b)

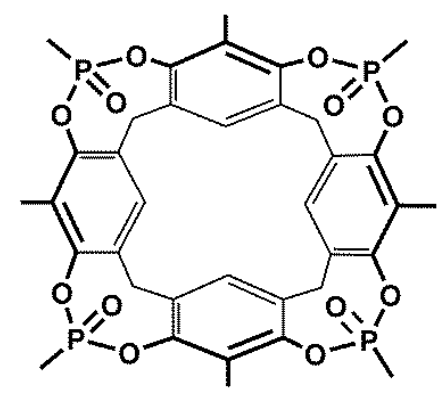

$\mathrm{Tiiii}\left[\mathrm{H}, \mathrm{CH}_{3}, \mathrm{CH}_{3}\right]$

Scheme 1. Molecular sketch of the (a) side and (b) top view of cavitand Tiiii $\left[\mathrm{H}, \mathrm{CH}_{3}, \mathrm{CH}_{3}\right]$.

The analysis of the diffraction patterns revealed that the single crystals obtained by co-crystallization of the cavitand in the presence of the fully protonated amino acids were monoclinic (P2 1 space group) for the Arg and His complexes, while the Tiiii/Lys complex crystallized in the orthorhombic $\mathrm{P}_{2} 2_{1} 2$ space group. The asymmetric unit of the $2 \mathrm{Tiiii}\left[\mathrm{H}, \mathrm{CH}_{3}, \mathrm{CH}_{3}\right] \bullet \mathrm{Arg} \cdot 2 \mathrm{HCl}$ and 2 Tiiii $\left[\mathrm{H}, \mathrm{CH}_{3}, \mathrm{CH}_{3}\right] \bullet \mathrm{Lys} \cdot 2 \mathrm{HCl}$ crystal structures is composed of two host and one guest molecule, forming a 2:1 host-guest ditopic complex (Figure $1 \mathrm{a}, \mathrm{b}$ ), while, in the $2 \mathrm{Tiiii}\left[\mathrm{H}, \mathrm{CH}_{3}, \mathrm{CH}_{3}\right] \bullet \mathrm{His} \cdot 2 \mathrm{HCl}$ crystal structure, four crystallographically independent cavitands and two amino acids molecules form a sort of dimeric 2:1 host-guest ditopic complex (Figure 1c).

In all three structures, a chloride ion was modeled at the lower rim of the cavitand, forming weak $\mathrm{C}-\mathrm{H} \cdots \mathrm{Cl}^{-}$interactions with the aromatic $\mathrm{CH}$ fragments (green spheres in Figure 1).

The relevant geometric parameters describing the host-guest interactions are reported in Table 1. The X-ray structure determination revealed two binding geometries for the side chain fragments of arginine, lysine, and histidine. Guanidinium, ammonium, and imidazolium cationic groups of the side chain are hosted in the cavity of the phosphonate receptor, and are held in place by specific hydrogen bonding interactions with the $\mathrm{P}=\mathrm{O}$ groups of a cavitand molecule (Figures 2 and 3 ).

The guanidinium group of Arg was found to be statistically disordered over two equally populated positions (conformation I and II). In conformation I, the side chain of Arg interacts with all four $\mathrm{P}=\mathrm{O}$ groups of Tiiii (Table 1 and Figure $2 \mathrm{a}, \mathrm{b}$ ), and its terminal atoms are inserted below the main plane, defined by the oxygen atoms of the $\mathrm{P}=\mathrm{O}$ groups. The planar guanidinium group forms a dihedral angle of $40^{\circ}$ with the mean plane of the four oxygen atoms of the $\mathrm{P}=\mathrm{O}$ groups of Tiiii host. In conformation II, the planar guanidinium group is more perpendicular with respect to the oxygen atoms' plane (dihedral angle of $63^{\circ}$ ), and forms only two strong $\mathrm{H}$-bonds with two opposite $\mathrm{P}=\mathrm{O}$ 
groups (Table 1 and Figure 2c,d). In this case, a $\mathrm{NH}_{2}$ group is located in the center of the cavity of the tetraphosphonate host, and it is slightly more deeply inserted in the cavity with respect to the other conformation (Table 1 and Figure $2 \mathrm{~b}, \mathrm{~d}$ ).

The ammonium group of Lys, located above the $\mathrm{P}=\mathrm{O}$ plane, interacts and forms strong $\mathrm{H}$-bonds with two adjacent $\mathrm{P}=\mathrm{O}$ groups of Tiiii (Table 1 and Figure $3 \mathrm{a}, \mathrm{b}$ ) and with a water molecule inserted in the Tiiii cavity. This internal water molecule forms two H-bonds with the remaining oxygen atoms of the $\mathrm{P}=\mathrm{O}$ groups (Table 1 and Figure $3 \mathrm{a}, \mathrm{b}$ ).

Table 1. Relevant geometric parameters ( $⿱$ ) describing the host-guest interactions. Tiiii(1) and Tiiii(2) cavitands form $\mathrm{H}$-bonds with the $\alpha$-ammonium group and with the side chain of the amino acid, respectively. The out of plane (oop) of the more inserted non- $\mathrm{H}$ atoms of the amino acid (or water molecule) is calculated with respect to the mean plane, defined by the four oxygen atoms of the cavitand $\mathrm{P}=\mathrm{O}$ groups. A negative sign is used for atoms below the plane and inserted in the cavity of Tiiii. His(1) and His(2) correspond to the two crystallographic independent molecules of the dimeric $2 \mathrm{Tiiii}\left[\mathrm{H}, \mathrm{CH}_{3}\right.$, $\left.\mathrm{CH}_{3}\right] \bullet \mathrm{His} \cdot 2 \mathrm{HCl}$ complex. Values in brackets correspond to the II conformation of Arg.

\begin{tabular}{|c|c|c|c|c|}
\hline Tiiii(1) H-Bonds & Arg & Lys & His(1) & $\operatorname{His}(2)$ \\
\hline $\mathrm{N}-\mathrm{O}_{2}$ & 2.71 . & 2.71 . & 2.81 . & 2.71 . \\
\hline $\mathrm{N}-\mathrm{O}_{3}$ & 2.80 & 2.83 & 2.77 & 2.78 \\
\hline $\mathrm{N}-\mathrm{O}_{\mathrm{W}}$ & 2.74 & 2.72 & 2.64 & 2.66 \\
\hline $\mathrm{O}_{\mathrm{W}}-\mathrm{O}_{1}$ & 2.90 & 2.87 & 2.76 & 2.81 \\
\hline $\mathrm{O}_{\mathrm{W}}-\mathrm{O}_{4}$ & 2.83 & 2.90 & 2.73 & 2.87 \\
\hline oop $\mathrm{N}$ & 0.70 & 0.55 & 0.89 & 0.89 \\
\hline oop $\mathrm{O}_{\mathrm{w}}$ & -0.65 & -0.86 & 0.36 & 0.13 \\
\hline Tiiii(2) H-Bonds & Arg & Lys & His(1) & $\operatorname{His}(2)$ \\
\hline $\mathrm{O}_{1}$ & $\mathrm{~N}_{\eta 2} 2.93(2.70)$ & $\mathrm{N}_{\zeta} 2.84$ & $\mathrm{~N}_{\delta 1} 2.70$ & $\mathrm{~N}_{\delta 1} 2.69$ \\
\hline $\mathrm{O}_{2}$ & $\mathrm{~N}_{\eta 1} 2.92(3.47)$ & $\mathrm{N}_{\zeta} 2.76$ & & \\
\hline $\mathrm{O}_{3}$ & $\mathrm{~N}_{\varepsilon} 2.76$ & $\mathrm{O}_{\mathrm{w}} 2.68$ & $\mathrm{~N}_{\varepsilon 2} 2.71$ & $\mathrm{~N}_{\delta 1} 2.67$ \\
\hline $\mathrm{O}_{4}$ & $\mathrm{~N}_{\eta 2} 2.73(3.45)$ & $\mathrm{O}_{\mathrm{w}} 2.71$ & & \\
\hline $\mathrm{O}_{\mathrm{w}}$ & & $\mathrm{N}_{\zeta} 2.72$ & & \\
\hline oop & $\mathrm{N}_{\eta 1}-0.54(-0.64)$ & $\mathrm{N}_{\zeta} 0.72$ & $\mathrm{C}_{\varepsilon 1}-0.47$ & $\mathrm{C}_{\varepsilon 1}-0.38$ \\
\hline oop & & $\mathrm{O}_{\mathrm{w}} 0.29$ & & \\
\hline
\end{tabular}

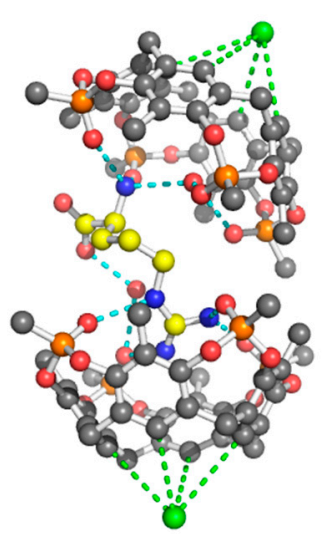

(a)

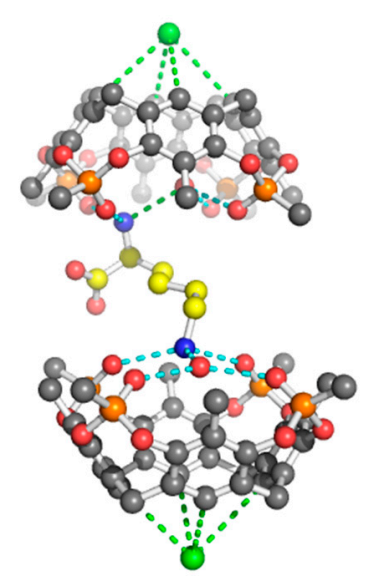

(b)

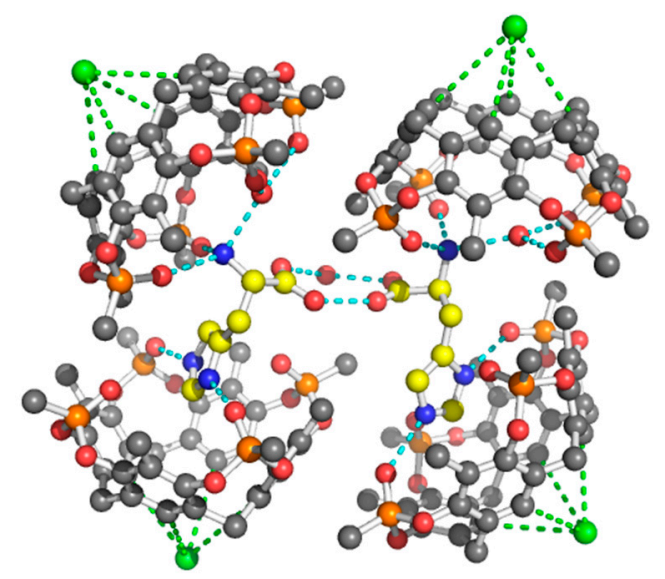

(c)

Figure 1. Ball and stick models of the crystallographic host-guest complexes. CPK colors with the amino acid guests evidenced by yellow carbon atoms. Hydrogen atoms have been omitted for clarity. The H-bonds are represented by cyan dashed lines. The chloride anions (green spheres) form weak $\mathrm{C}-\mathrm{H} \cdots \mathrm{Cl}^{-}$interactions (green dashed lines) with the lower rim of the cavitand (a) $2 \mathrm{Tiiii}\left[\mathrm{H}, \mathrm{CH}_{3}\right.$, $\left.\mathrm{CH}_{3}\right] \bullet \mathrm{Arg} \cdot 2 \mathrm{HCl}$ 2:1 ditopic complex (b) 2 Tiiii[H, $\left.\mathrm{CH}_{3}, \mathrm{CH}_{3}\right] \bullet$ Lys.2HCl 2:1 ditopic complex (c) dimeric $2 \mathrm{Tiiii}\left[\mathrm{H}, \mathrm{CH}_{3}, \mathrm{CH}_{3}\right] \bullet \mathrm{His} \cdot 2 \mathrm{HCl}$ 2:1 ditopic complex. 


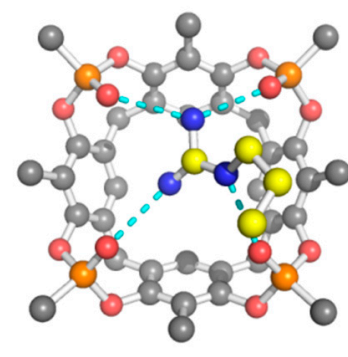

(a)

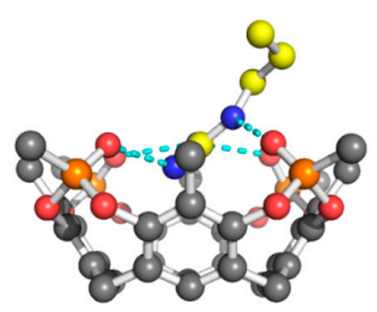

(b)

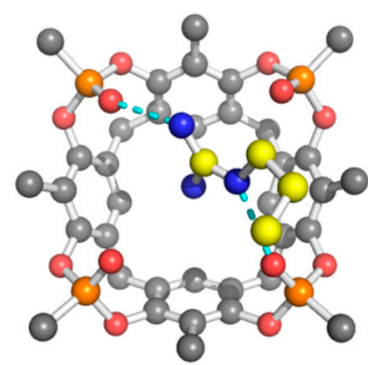

(c)

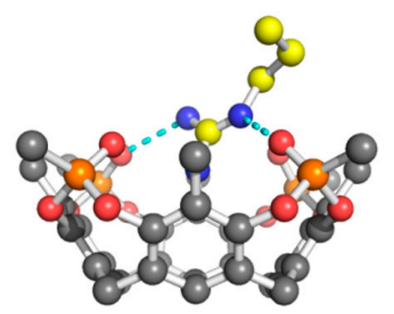

(d)

Figure 2. Orthogonal views of the H-bond interactions (cyan dashed lines) between the side chain of Arg amino acid (yellow carbons) and tetraphosphonate cavitand Tiiii (grey carbons) (a,b) conformation I; (c,d) conformation II. Other atoms color code: P, orange; N, blue; $\mathrm{O}$, red. Hydrogen atoms have been omitted for clarity.

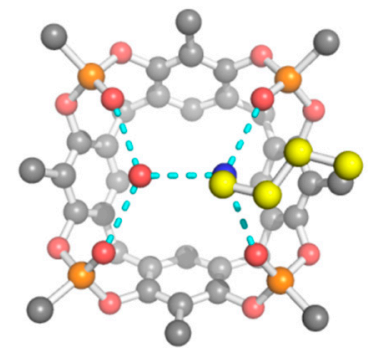

(a)

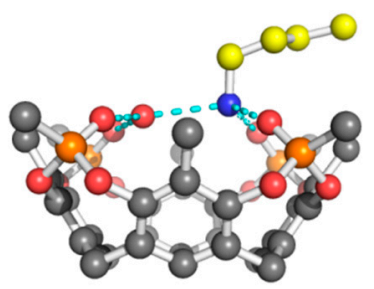

(b)

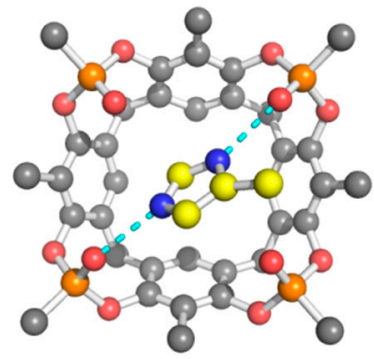

(c)

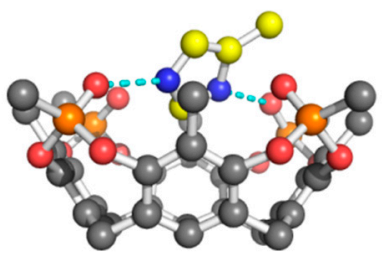

(d)

Figure 3. Orthogonal views of the H-bond interactions (cyan dashed lines) between the amino acid side chain (yellow carbons) and tetraphosphonate cavitand (black carbons) (a,b) 2 Tiiii[ $\left[\mathrm{H}, \mathrm{CH}_{3}, \mathrm{CH}_{3}\right] \bullet$ Lys $2 \mathrm{HCl}$ complex; (c,d) $2 \mathrm{Tiiii}\left[\mathrm{H}, \mathrm{CH}_{3}, \mathrm{CH}_{3}\right] \bullet \mathrm{His} 2 \mathrm{HCl}$ complex. Hydrogen atoms have been omitted for clarity. 
In the His crystal, both crystallographically independent 2:1 host-guest complexes have a very similar side chain interaction with the cavitand (Figure 1c). The imidazolium cationic group of the His amino acid is inserted with its $C_{\varepsilon 1}$ atom into the center of the cavity, and it forms two strong $\mathrm{H}$-bonds with two opposite $\mathrm{P}=\mathrm{O}$ groups (Table 1 and Figure $3 \mathrm{c}, \mathrm{d}$ ). The dihedral angle between the imidazolium group and the oxygen atoms plane of Tiiii is $57^{\circ}$ and $67^{\circ}$, in the two crystallographically independent complexes, respectively. It is interesting to note that, while the interaction of the Lys side chain is assisted by a buried water molecule, no extra water molecules are presented in the cavity of Tiiii hosting the Arg or His side chains. This is probably due to the fact that the guanidinium and imidazolium groups are able to form $\mathrm{H}$-bonds with two opposite $\mathrm{P}=\mathrm{O}$ groups (see Figures $2 \mathrm{c}$ and $3 c)$. In such arrangements, a water molecule does not have enough space inside the cavity and any possibility to form double $\mathrm{H}$-bonds with two vicinal $\mathrm{P}=\mathrm{O}$ groups, as in the case of the complexes with the ammonium group (Figures $3 a$ and $4 a$ ). On the other hand, Lys side chain has a higher charge density compared with the Arg and His side chains, in which the conjugation between double bond and nitrogen lone pairs delocalizes the positive charge. Consequently, desolvation of the planar guanidinium and imidazolium groups should be more favorable with respect to the ammonium group of Lys amino acid.

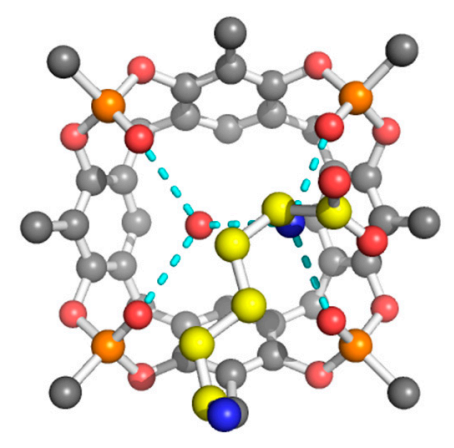

(a)

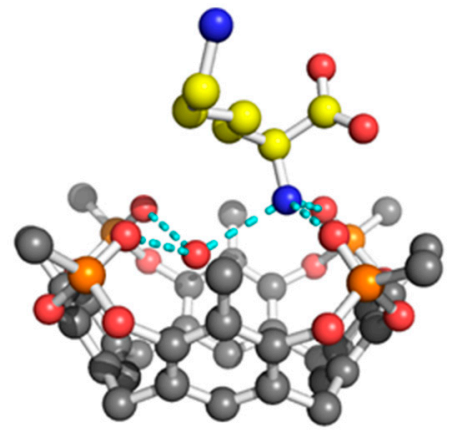

(b)

Figure 4. Orthogonal views of the H-bond interactions (cyan dashed lines) between the $\alpha$-ammonium group of Lys amino acid (yellow carbons) and Tiiii (gray carbons) mediated by a water molecule (red sphere). Hydrogen atoms have been omitted for clarity. (a) top view (b) side view.

In all three structures, the fully protonated form of the amino acid is ditopically complexed (Figure 1). The positively charged $\alpha$-ammonium groups form $\mathrm{H}$-bonds with the $\mathrm{P}=\mathrm{O}$ groups, and with a water molecule hosted in the cavity of a second tetraphosphonate molecule. The nitrogen atom is above the $\mathrm{O}$ mean plane, defined by the oxygen atoms of the $\mathrm{P}=\mathrm{O}$ units, while the water molecule is located below this plane (Figure 4). More specifically, in the Lys complex, this water molecule is much more inserted in the cavity with respect to the analogous water molecule on the opposing cavitand that hosts the $\zeta$-ammonium group (1.15 $\AA$, see Table 1$)$. This different behavior can be associated with the presence, in the $\alpha$ ammonium group complexation, of a methylene $\beta$ carbon that covers the cavity (Figure 4a). On the other hand, the complexation of the linear side chain of Lys leaves the water molecule free to adopt a different position in the hydrophobic cavity (Figure 3a).

This amino acid/cavitand interaction mediated by a water molecule has been observed in all three complexes, namely with Arg, Lys, and His, and it involves the constant part of the $\alpha$-amino acid. This "nonspecific" amino acid H-bond interaction was already reported in previously determined host-guest complexes involving the hydrophobic amino acids: Ala, Val, Leu, and Ile [35].

A particular H-bond interaction between the carboxylic acid group of $\mathrm{Arg}$ and a $\mathrm{P}=\mathrm{O}$ group of cavitand mediated by a water molecule has been observed (Figure 5a). This interaction, noted only 
in 2 Tiiii $\left[\mathrm{H}, \mathrm{CH}_{3}, \mathrm{CH}_{3}\right] \bullet A r g$ 2 $\mathrm{HCl}$ complex, links the two cavitands of the 2:1 complex by an H-bond network that involves the $\alpha$-ammonium and $\alpha$-carboxylic acid groups of the guest.

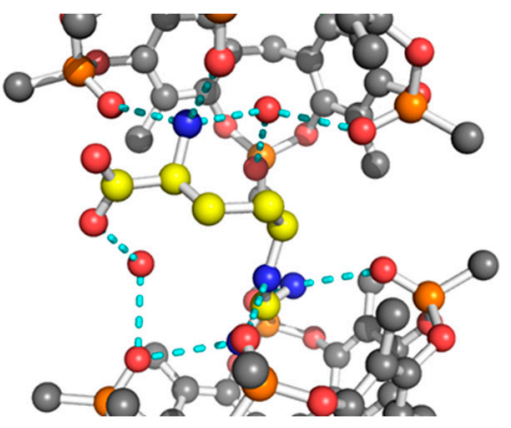

(a)

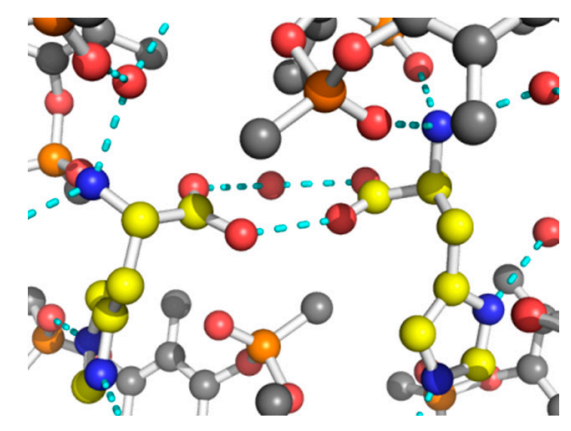

(b)

Figure 5. H-bond interactions between the amino acid (yellow carbons) and tetraphosphonate cavitand (gray carbons) (a) H-bond interaction between the carboxylic acid group of Arg amino acid and Tiiii mediated by a water molecule (red sphere); (b) dimerization of the $2 \mathrm{Tiiii}\left[\mathrm{H}, \mathrm{CH}_{3}, \mathrm{CH}_{3}\right] \bullet \mathrm{His} 2 \mathrm{HCl}$ complex mediated by a water molecule (red sphere). Hydrogen atoms have been omitted for clarity.

An interesting difference within the positively charge proteinogenic amino acids is the formation, in the solid state, of water-assisted dimerization of the cavitand/histidine 2:1 complex. In this structure, a bridged water molecule is held by two carboxylic acid groups of the dimerized amino acid (Figure 5b). From the topological point of view, this dimer shows that the couple of 2:1 complexes are mutually oriented in such a way that the side chain of the guest amino acid has the same direction and orientation (Figure 1c).

The cavitand units of the 2:1 complexes are in a typical cone conformation with the amino acid guest, connecting the two bowls, oriented slantwise to allow for optimal host-guest interaction. Despite the formation of 2:1 complexes with similar $\alpha$-ammonium/Tiiii interaction and analogue side chain complexation, the crystal structures of the three amino acid/cavitand complexes show a quite different spatial arrangement of the two cavitands.

The overall shape of the $2 \mathrm{Tiiii}\left[\mathrm{H}, \mathrm{CH}_{3}, \mathrm{CH}_{3}\right] \bullet \mathrm{Arg} 2 \mathrm{HCl}$ complex is quasi-capsular, with the Arg amino acid captured between the two almost-aligned cavitands. In particular, the two bowls, facing each other, hold the Arg amino acid in a clamp-like arrangement. The dihedral angle between the mean planes of the four oxygen atoms of the $\mathrm{P}=\mathrm{O}$ groups of two cavitands, representing the opening angle of the clamp, is $36^{\circ}$ (Figure 6a).

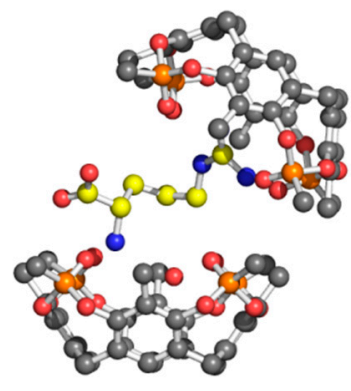

(a)

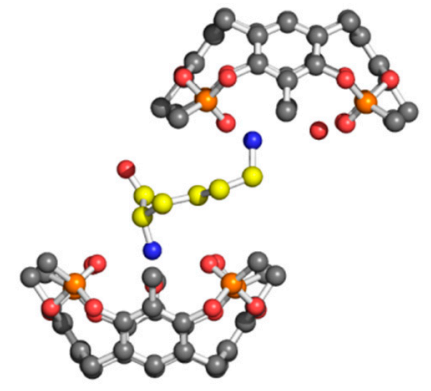

(b)

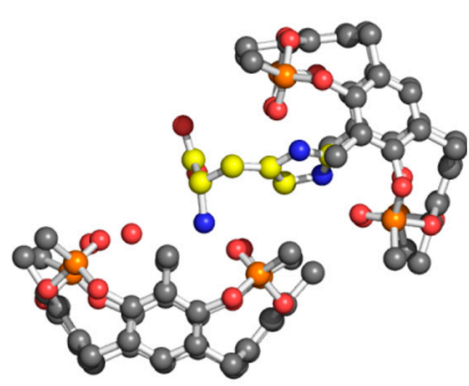

(c)

Figure 6. Ball and stick models of the Tiiii/amino acid 2:1 complexes view parallel to the mean planes of the four oxygen atoms of the $\mathrm{P}=\mathrm{O}$ groups of Tiiii hosts (a) $2 \mathrm{Tiiii}\left[\mathrm{H}, \mathrm{CH}_{3}, \mathrm{CH}_{3}\right] \bullet \mathrm{Arg} 2 \mathrm{HCl}$ 2:1 ditopic complex (b) 2 Tiiii $\left[\mathrm{H}, \mathrm{CH}_{3}, \mathrm{CH}_{3}\right] \bullet \mathrm{Lys} 2 \mathrm{HCl}$ 2:1 ditopic complex (c) $2 \mathrm{Tiiii}\left[\mathrm{H}, \mathrm{CH}_{3}, \mathrm{CH}_{3}\right] \bullet \mathrm{His} 2 \mathrm{HCl}$ 2:1 ditopic complex. Hydrogen atoms have been omitted for clarity. 
In the 2 Tiiii $\left[\mathrm{H}, \mathrm{CH}_{3}, \mathrm{CH}_{3}\right] \bullet$ Lys $2 \mathrm{HCl}$ complex, the two cavitand bowls are almost perfectly anti-parallel, while they are offset by about a half cavitand (Figure 6b). This misalignment significantly opens the clamp formed by the two host molecules.

In the 2 Tiiii $\left[\mathrm{H}, \mathrm{CH}_{3}, \mathrm{CH}_{3}\right] \bullet \mathrm{His} 2 \mathrm{HCl}$ complex, the two cavitand bowls are both shifted laterally, by more than half cavitand, and rotated by about $48^{\circ}$ (dihedral angle between the $\mathrm{P}=\mathrm{O}$ planes), resulting in a more open clamp with respect to the other two cases (Figure 6c).

With respect to the ditopic behavior of positively charge amino acids, an unexpected result obtained in this crystal structure analysis is the trend observed in the opening of the clamp of the 2:1 complex. The trend observed, His $>$ Lys $>$ Arg, is in reverse order with respect to the length of amino acid side chain Arg > Lys $>$ His. This reverse trend can be attributed to dimer formation, in the case of the 2 Tiiii $\left[\mathrm{H}, \mathrm{CH}_{3}, \mathrm{CH}_{3}\right] \bullet \mathrm{His} 2 \mathrm{HCl}$ complex (Figure 1c), and to the different behavior between Arg and Lys residues in the insertion of the side chain into the cavitand (Table 1 and Figures $2 b$ and $3 b$ ).

\section{Materials and Methods}

\subsection{Co-Crystallization Experiments}

For the co-crystallization experiments, the phosphonate cavitand $\operatorname{Tiii}\left[\mathrm{H}, \mathrm{CH}_{3}, \mathrm{CH}_{3}\right]$, with the $\mathrm{P}=\mathrm{O}$ groups pointing inward the cavity, was synthesized as previously described [45], and 2,2,2-trifluoroethanol (TFE) and amino acids (L-arginine, L-lysine, and L-histidine) were purchased from Sigma-Aldrich (St. Louis, MO, USA), and used as supplied.

Crystals of host-guest complexes containing amino acids were obtained by co-crystallization microscale experiments with the sitting drop vapor diffusion technique. The co-crystallization solution was prepared by adding, to a TFE solution $\left(30 \mathrm{mM}\right.$ ) of cavitand Tiiii $\left[\mathrm{H}, \mathrm{CH}_{3}, \mathrm{CH}_{3}\right]$, a solution containing the desired amino acid. The solutions of amino acids were prepared in $1 \mathrm{M} \mathrm{HCl}$ (see Table S1 for experimental details). As a general procedure, $4 \mu \mathrm{L}$ of the solution containing the cavitand and the amino acid were set on a microbridge, and then $4 \mu \mathrm{L}$ of the reservoir solution were added to the drop. The drop was left to equilibrate against $1 \mathrm{~mL}$ of reservoir solution, containing the organic polymer polyethylene glycol (PEG) 300 in the range between 5 and $50 \%(v / v)$ as precipitant agent. Crystals were left to grow at the temperatures of $4{ }^{\circ} \mathrm{C}$. After 1 month, good quality crystals suitable for X-ray diffraction analysis were obtained.

\subsection{Crystal Structure Determination}

Data collections were carried out at the Macromolecular crystallography XRD1 beamline of the Elettra synchrotron (Trieste, Italy), by employing the rotating crystal method and the cryo-cooling technique. Routinely, the crystal was mounted in a loop and flash frozen at $100 \mathrm{~K}$ with liquid nitrogen without adding further cryoprotectant, thanks to the presence of PEG 300 in the mother liquor. Diffraction data of Arg, Lys, and His/cavitand complexes were indexed and integrated using the XDS package [46]. Scaling was carried out with AIMLESS, for the dataset collected from crystals of Arg, Lys, and His/cavitand supramolecular complexes.

All structures were solved by direct methods using SIR2011 [47]. Non-hydrogen atoms at full occupancy, or with population higher than 0.5 , were anisotropically refined ( $\mathrm{H}$ atoms at the calculated positions) by full-matrix least-squares methods on $F^{2}$ using SHELXL-13. Restraints on the geometrical and thermal parameters of the disordered solvent molecules (DFIX, DELU, ISOR) were introduced during the last refinement cycles. Several TFE co-crystallized solvent molecules were found in the asymmetric units for all the structures. In all the structures, electronic density that could be attributed to highly disordered solvent molecules was detected. The contribute of the disordered solvent to the overall scattering was removed through the SQUEEZE function of PLATON software [48]. A detailed discussion of the refinement for each structure is provided below. 


\subsubsection{Structure Refinement of $2 \mathrm{Tiiii}\left[\mathrm{H}, \mathrm{CH}_{3}, \mathrm{CH}_{3}\right] \bullet \mathrm{Arg} 2 \mathrm{HCl}$ Complex}

In the asymmetric unit of the complex of Tiiii $\left[\mathrm{H}, \mathrm{CH}_{3}, \mathrm{CH}_{3}\right]$ with doubly protonated $\mathrm{Arg}$, a dimeric supramolecular host-guest complex was found together with 2.9 TFE solvent molecules and 3.7 water molecules. The guanidinium fragment of arginine was found disordered over two positions refined with equal occupancy. The residual electron density of 155 electrons/cell, found in the voids of the crystal (corresponding to $9 \%$ of the cell volume), was attributed to about 1.5 highly disordered $\mathrm{CF}_{3} \mathrm{CH}_{2} \mathrm{OH}$ molecules in asymmetric units. A refinement using reflections modified by the SQUEEZE procedure [48] behaved well, and the $R$-factor was reduced from $9.1 \%$ to $7.5 \%$.

\subsubsection{Structure Refinement of $2 \mathrm{Tiiii}\left[\mathrm{H}, \mathrm{CH}_{3}, \mathrm{CH}_{3}\right] \bullet$ Lys $2 \mathrm{HCl}$ Complex}

In the asymmetric unit of the crystal of the complex of Tiiii $\left[\mathrm{H}, \mathrm{CH}_{3}, \mathrm{CH}_{3}\right]$ with doubly protonated Lys, a dimeric host-guest complex was detected together with 0.8 TFE solvent molecules and 2.8 water molecules. The residual electron density of 1097 electrons/cell, found in the voids of the crystal (corresponding to $28 \%$ of the cell volume), was attributed to a disordered chlorine ion and about 5.3 $\mathrm{CF}_{3} \mathrm{CH}_{2} \mathrm{OH}$ molecules in asymmetric units. A refinement using reflections modified by the SQUEEZE procedure [48] behaved well, and the $R$-factor was reduced from $14.3 \%$ to $6.8 \%$.

\subsubsection{Structure Refinement of $2 \mathrm{Tiiii}\left[\mathrm{H}, \mathrm{CH}_{3}, \mathrm{CH}_{3}\right] \bullet \mathrm{His} 2 \mathrm{HCl}$ Complex}

In the asymmetric unit of the crystal of the complex 2 Tiiii $\left[\mathrm{H}, \mathrm{CH}_{3}, \mathrm{CH}_{3}\right]$ with doubly protonated His, two crystallographically independent dimeric host-guest complexes were detected together with 7.82 TFE solvent molecules and four water molecules. The residual electron density of 191.7 electrons/cell, found in the voids of the crystal (corresponding to $7 \%$ of the cell volume), was attributed to about $2.1 \mathrm{CF}_{3} \mathrm{CH}_{2} \mathrm{OH}$ molecules in asymmetric units. A refinement using reflections modified by the SQUEEZE procedure behaved well, and the $R$-factor was reduced from $7.4 \%$ to $6.8 \%$.

Crystal data and refinement details are reported in Table S2. CCDC 1869186 (Tiiii/His), 1869187 (Tiiii/Arg), and 1876524 (Tiiii/Lys) contain the supplementary crystallographic data for this paper. These data can be obtained free of charge via http:/ / www.ccdc.cam.ac.uk/conts/retrieving. html (or from the CCDC, 12 Union Road, Cambridge CB2 1EZ, UK; Fax: +44-1223-336033; E-mail: deposit@ccdc.cam.ac.uk)

\section{Conclusions}

Molecular recognition of amino acids is a topic of particular interest because it involves several important applicative aspects, such as advanced therapeutic approaches towards target proteins, as well as sensor applications for biochemical analysis and immobilization techniques for protein purification and/or characterization [38,49]. Within a systematic crystallization program, to assess the complexation properties of a cavitand molecule towards amino acids [35], we obtained crystals of the fully protonated form of the three proteinogenic positively charged amino acids, Arg, Lys, and His complexed with the tetraphosphonate cavitand Tiiii $\left[\mathrm{H}, \mathrm{CH}_{3}, \mathrm{CH}_{3}\right]$ in cone conformation. The X-ray structure revealed that, in all three complexes, the fully protonated form of these amino acids has a ditopic behavior. Each amino acid is complexed by two tetraphosphonate cavitand molecules. The side chain of the amino acid is hosted by a cavitand molecule from one side, while the $\alpha$-ammonium group interacts with a second cavitand molecule on the opposite side. Then, an overall 2:1 host-guest complex is assembled. In particular, the guanidinium, ammonium, and imidazolium cationic groups of the side chain of the amino acids, Arg, Lys, and His, are respectively hosted in the cavity of a phosphonate receptor, and they are held in place by specific hydrogen bonding interactions with the $\mathrm{P}=\mathrm{O}$ groups of the cavitand molecule. The positively charged $\alpha$-ammonium group of the three amino acids forms $\mathrm{H}$-bonds with two $\mathrm{P}=\mathrm{O}$ groups, and with a water molecule hosted in the cavity of a second tetraphosphonate molecule. The chloride counter ion has a crucial role in the stabilization of this complex because it has been detected at the bottom of the lower rim of both cavitands, just on 
the opposite site of the cavity. The chloride ions form weak $\mathrm{C}-\mathrm{H} \cdots \mathrm{Cl}^{-}$interactions with the aromatic $\mathrm{CH}$ fragments of both Tiiii units, balancing the two positive charges of the guest. It is interesting to note that, in the solid state, the cavitand/histidine 2:1 complex forms a dimer through the carboxylic acid group of the amino acid. This dimerization, with formation of a supramolecular 4:2 host-guest complex, is assisted by a crucial bridged water molecule. This phenomenon has been observed only for this specific amino acid complex. The analysis of the relative disposition of the cavitands in the 2:1 host-guest complexes has evidenced an unexpected ditopic behavior of the proteinogenic positively charged amino acids. In particular, the trend observed in the opening of the clamp formed by the two cavitands, His $>$ Lys $>$ Arg, is inverted with respect to the trend of the length of amino acid side chain Arg > Lys > His. The bulkiest guest, Arg, is almost completely encapsulated by two phosphonate cavitands, while the shorter Lys and the even shorter His gradually show a more open structure of the complex. The overall architecture observed in these complexes provide support for the rational design of ditopic cavitands as molecular clamps for encapsulation of proteinogenic positively charged amino acids. [50,51].

Supplementary Materials: The following are available online. Table S1: Experimental details for the co-crystallization experiments of the host-guest complexes of cavitand Tiiii[ $\left.\mathrm{H}, \mathrm{CH}_{3}, \mathrm{CH}_{3}\right]$ with the selected amino acids., Table S2: Crystal data and structure refinement details for the host-guest complexes.

Author Contributions: Conceptualization, R.P. and S.G.; Methodology, E.D.; Formal Analysis, G.B.; Investigation, G.B., R.P., E.D., S.G.; Data Curation, G.B.; Writing-Original Draft Preparation, R.P., S.G.; Writing—Review and Editing, E.D.; Funding Acquisition, S.G.

Funding: The University of Trieste is acknowledged for financial support, FRA2016.

Acknowledgments: We thank the Elettra Synchrotron (Trieste, Italy) and the staff of the XRD1 beamline for their technical assistance.

Conflicts of Interest: The authors declare no conflict of interest.

\section{References}

1. Tapiero, H.; Mathé, G.; Couvreur, P.; Tew, K.D. Arginine. Biomed. Pharmacother. 2002, 56, 439-445. [CrossRef]

2. Stechmiller, J.K.; Childress, B.; Cowan, L. Arginine Supplementation and Wound Healing. Nutr. Clin. Pract. 2005, 20, 52-61. [CrossRef] [PubMed]

3. Vila, J.A.; Ripoll, D.R.; Villegas, M.E.; Vorobjev, Y.N.; Scheraga, H.A. Role of Hydrophobicity and Solvent-Mediated Charge-Charge Interactions in Stabilizing $\alpha$-Helices. BioPhys. J. 1998, 75, 2637-2646. [CrossRef]

4. Strickler, S.S.; Gribenko, A.V.; Gribenko, A.V.; Keiffer, T.R.; Tomlinson, J.; Reihle, T.; Loladze, V.V.; Makhatadze, G.I. Protein Stability and Surface Electrostatics: A Charged Relationship. Biochemistry 2006, 45, 2761-2766. [CrossRef]

5. Borders, C.L., Jr.; Broadwater, J.A.; Bekeny, P.A.; Salmon, J.E.; Lee, A.S.; Eldridge, A.M.; Pett, V.B. A structural role for arginine in proteins: Multiple hydrogen bonds to backbone carbonyl oxygens. Protein Sci. 1994, 3, 541-548. [CrossRef]

6. Tsukada, Y.; Fang, J.; Erdjument-Bromage, H.; Warren, M.E.; Borchers, C.H.; Tempst, P.; Zhang, Y. Histone demethylation by a family of JmjC domain-containing proteins. Nature 2006, 439, 811-816. [CrossRef]

7. Stewart, M.D.; Li, J.; Wong, J. Relationship between Histone H3 Lysine 9 Methylation, Transcription Repression, and Heterochromatin Protein 1 Recruitment. J. Mol. Cell. Biol. 2005, 25, 2525-2538. [CrossRef] [PubMed]

8. Nakayama, J.; Rice, J.C.; Strahl, B.D.; Allis, C.D.; Grewal, S.I. Role of Histone H3 Lysine 9 Methylation in Epigenetic Control of Heterochromatin Assembly. Science 2001, 292, 110-113. [CrossRef] [PubMed]

9. Chen, G.N.; Wu, X.P.; Duan, J.P.; Chen, H.Q. A study on electrochemistry of histidine and its metabolites based on the diazo coupling reaction. Talanta 1999, 49, 319-330.

10. Liao, S.-M.; Du, Q.-S.; Meng, J.-Z.; Pang, Z.-W.; Huang, R.-B. The multiple roles of histidine in protein interactions. Chem. Cent. J. 2013, 7, 44. [CrossRef] 
11. Beadle, C.; Long, G.W.; Weiss, W.R.; McElroy, P.D.; Maret, S.M.; Oloo, A.J.; Hoffman, S.L. Diagnosis of malaria by detection of Plasmodium falciparum HRP-2 antigen with a rapid dipstick antigen-capture assay. Lancet 1994, 343, 564-568. [CrossRef]

12. Chen, H.; Gu, L.; Yin, Y.; Koh, K.; Lee, J. Molecular Recognition of Arginine by Supramolecular Complexation with Calixarene Crown Ether Based on Surface Plasmon Resonance. Int. J. Mol. Sci. 2011, 12, 2315-2324. [CrossRef] [PubMed]

13. Fokkens, M.; Schrader, T.; Klärner, F.-G. A Molecular Tweezer for Lysine and Arginine. J. Am. Chem. Soc. 2005, 127, 14415-14421. [CrossRef] [PubMed]

14. Ngola, S.M.; Kearney, P.C.; Mecozzi, S.; Russell, K.; Dougherty, D.A. A Selective Receptor for Arginine Derivatives in Aqueous Media. Energetic Consequences of Salt Bridges that Are Highly Exposed to Water. J. Am. Chem. Soc. 1999, 121, 1192-1201. [CrossRef]

15. Julian, R.R.; Akin, M.; May, J.A.; Stoltz, B.M.; Beauchamp, J.L. Molecular recognition of arginine in small peptides by supramolecular complexation with dibenzo-30-crown-10 ether. Int. J. Mass Spectrom. 2002, 220, 87-96. [CrossRef]

16. Chen, Z.; Liu, J.; Han, Y.; Zhu, L. A novel histidine assay using tetraphenylporphyrin manganese (III) chloride as a molecular recognition probe by resonance light scattering technique. Anal. Chim. Acta 2006, 570, 109-115. [CrossRef]

17. Cram, D.J.; Cram, J.M. Container Molecules and Their Guests; Stoddart, J.F., Ed.; The Royal Society of Chemistry: Cambridge, UK, 1994.

18. Pinalli, R.; Pedrini, A.; Dalcanale, E. Cavitands. In Comprehensive Supramolecular Chemistry II; Atwood, J.L., Ed.; Elsevier: Amsterdam, The Netherlands, 2017; pp. 87-115. ISBN 9780128031995.

19. Pinalli, R.; Dalcanale, E.; Ugozzoli, F.; Massera, C. Resorcinarene-based cavitands as building blocks for crystal engineering. CrystEngComm 2016, 18, 5788-5802. [CrossRef]

20. Rebek, J., Jr. Molecular Recognition with Model Systems. Angew. Chem. Int. Ed. Engl. 1990, 29, $245-255$. [CrossRef]

21. Hunter, C.H.; Lawson, K.R.; Perkins, J.; Urch, C.J. Aromatic interactions. J. Chem. Soc., Perkin Trans. 2001, 2, 651-669. [CrossRef]

22. Nishio, M.; Hirota, M.; Umezawa, Y. The CH- $\pi$ Interactions: Evidence, Nature and Consequences; Wiley-VCH: New York, NY, USA, 1998.

23. Dougherty, D.A. The Cation- $\pi$ Interaction. Acc. Chem. Res. 2013, 46, 885-893. [CrossRef]

24. Bianchi, F.; Mattarozzi, M.; Betti, P.; Bisceglie, F.; Careri, M.; Mangia, A.; Sidisky, L.; Ongarato, S.; Dalcanale, E. Innovative Cavitand-Based Sol-Gel Coatings for the Environmental Monitoring of Benzene and Chlorobenzenes via Solid-Phase Microextraction. Anal. Chem. 2008, 80, 6423-6430. [CrossRef]

25. Tudisco, C.; Fragalà, M.E.; Giuffrida, A.E.; Bertani, F.; Pinalli, R.; Dalcanale, E.; Compagnini, G.; Condorelli, G.G. Hierarchical Route for the Fabrication of Cavitand-Modified Nanostructured ZnO Fibers for Volatile Organic Compound Detection. J. Phys. Chem. C 2016, 120, 12611-12617. [CrossRef]

26. Trzciński, J.W.; Pinalli, R.; Riboni, N.; Pedrini, A.; Bianchi, F.; Zampolli, S.; Elmi, I.; Massera, C.; Ugozzoli, F.; Dalcanale, E. In Search of the Ultimate Benzene Sensor: The EtQxBox Solution. ACS Sensors 2017, 2, 590-598. [CrossRef] [PubMed]

27. Pinalli, R.; Pedrini, A.; Dalcanale, E. Environmental gas sensing with cavitands. Chem Eur. J. 2018, 24, 1010-1019. [CrossRef]

28. Giannetto, M.; Pedrini, A.; Fortunati, S.; Brando, D.; Milano, S.; Massera, C.; Tatti, R.; Verucchi, R.; Careri, M.; Dalcanale, E.; et al. Sensing of halogenated aromatic hydrocarbons in water with a cavitand coated piezoelectric device. Sens. Actuators B Chem. 2018, 276, 340-348. [CrossRef]

29. Maffei, F.; Betti, P.; Genovese, D.; Montalti, M.; Prodi, L.; De Zorzi, R.; Geremia, S.; Dalcanale, E. Highly Selective Chemical Vapor Sensing by Molecular Recognition: Specific Detection of $\mathrm{C}_{1}-\mathrm{C}_{4}$ Alcohols with a Fluorescent Phosphonate Cavitand. Angew. Chem. Int. Ed. 2011, 50, 4654-4657. [CrossRef]

30. Melegari, M.; Massera, C.; Pinalli, R.; Yebeutchou, R.M.; Dalcanale, E. Supramolecular sensing of short chain alcohols with mixed-bridged thio-phosphonate cavitands. Sens. Actuators B Chem. 2013, 179, 74-80. [CrossRef]

31. Dionisio, M.; Oliviero, G.; Menozzi, D.; Federici, S.; Yebeutchou, R.M.; Schmidtchen, F.P.; Dalcanale, E.; Bergese, P. Nanomechanical Recognition of N-Methylammonium Salts. J. Am. Chem. Soc. 2012, 134, 2392-2398. [CrossRef]

32. Pinalli, R.; Suman, M.; Dalcanale, E. Cavitands at work: From molecular recognition to supramolecular sensors. Eur. J. Org. Chem. 2004, 3, 451-462. [CrossRef] 
33. Biavardi, E.; Tudisco, C.; Maffei, F.; Motta, A.; Massera, C.; Condorelli, G.G.; Dalcanale, E. Exclusive recognition of sarcosine in water and urine by a cavitand-functionalized silicon surface. Proc. Natl. Acad. Sci. USA 2012, 109, 2263-2268. [CrossRef]

34. Valenti, G.; Rampazzo, E.; Biavardi, E.; Villani, E.; Fracasso, G.; Marcaccio, M.; Bertani, F.; Ramarli, D.; Dalcanale, E.; Paolucci, F.; et al. An electrochemiluminescence-supramolecular approach to sarcosine detection for early diagnosis of prostate cancer. Faraday Discuss. 2015, 185, 299-309. [CrossRef] [PubMed]

35. Pinalli, R.; Brancatelli, G.; Pedrini, A.; Menozzi, D.; Hernández, D.; Ballester, P.; Geremia, S.; Dalcanale, E. The origin of selectivity in the complexation of $N$-methyl amino acids by tetraphosphonate cavitands. J. Am. Chem. Soc. 2016, 138, 8569-8580. [CrossRef]

36. Liu, Y.; Perez, L.; Mettry, M.; Easley, C.J.; Hooley, R.J.; Zhong, W. Self-Aggregating Deep Cavitand Acts as a Fluorescence Displacement Sensor for Lysine Methylation. J. Am. Chem. Soc. 2016, 138, 10746-10749. [CrossRef]

37. Liu, Y.; Perez, L.; Gill, A.D.; Mettry, M.; Li, L.; Wang, Y.; Hooley, R.J.; Zhong, W. Site-Selective Sensing of Histone Methylation Enzyme Activity via an Arrayed Supramolecular Tandem Assay. J. Am. Chem. Soc. 2017, 139, 10964-10967. [CrossRef]

38. Pinalli, R.; Pedrini, A.; Dalcanale, E. Biochemical Sensing with cavitands. Chem. Soc. Rev. 2018, 47, 7006-7026. [CrossRef] [PubMed]

39. McGovern, R.E.; Fernandes, H.; Khan, A.R.; Power, N.P.; Crowley, P.B. Protein camouflage in cytochrome c-calixarene complexes. Nat. Chem. 2012, 4, 527-533. [CrossRef]

40. Rennie, M.L.; Fox, G.C.; Pérez, J.; Crowley, P.B. Auto-regulated Protein Assembly on a Supramolecular Scaffold. Angew. Chem. Int. Ed. 2018, 57, 13764-13769. [CrossRef]

41. McGovern, R.E.; McCarthy, A.A.; Crowley, P.B. Protein assembly mediated by sulfonatocalix[4]arene. Chem. Commun. 2014, 50, 10412-10415. [CrossRef]

42. Chinai, J.M.; Taylor, A.B.; Ryno, L.M.; Hargreaves, N.D.; Morris, C.A.; Hart, P.J.; Urbach, A.R. Molecular recognition of insulin by a synthetic receptor. J. Am. Chem. Soc. 2011, 133, 8810-8813. [CrossRef]

43. Guagnini, F.; Antonik, P.M.; Rennie, M.L.; O’Byrne, P.; Khan, A.R.; Pinalli, R.; Dalcanale, E.; Crowley, P.B. Cucurbit[7]uril-Dimethyllysine Recognition in a Model Protein. Angew. Chem. Int. Ed. 2018, 57, 7126-7130. [CrossRef]

44. Kumar, K.; Woo, S.M.; Siu, T.; Cortopassi, W.A.; Duarte, F.; Paton, R.S. Cation $-\pi$ interactions in protein-ligand binding: Theory and data-mining reveal different roles for lysine and arginine. Chem. Sci. 2018, 9, 2655-2665. [CrossRef] [PubMed]

45. Melegari, M.; Suman, M.; Pirondini, L.; Moiani, D.; Massera, C.; Ugozzoli, F.; Kalenius, E.; Vainiotalo, P.; Mulatier, J.-C.; Dutasta, J.-P.; et al. Supramolecular Sensing with Phosphonate Cavitands. Chem. Eur. J. 2008, 14, 5772-5779. [CrossRef] [PubMed]

46. Kabsch, W. XDS. Acta Cryst. 2010, D66, 125-132. [CrossRef] [PubMed]

47. Burla, M.C.; Caliandro, R.; Camalli, M.; Carrozzini, B.; Cascarano, G.L.; Giacovazzo, C.; Mallamo, M.; Mazzone, A.; Polidori, G.; Spagna, R. SIR2011: A new package for crystal structure determination and refinement. J. Appl. Cryst. 2012, 45, 357-361. [CrossRef]

48. Spek, A.L. PLATON SQUEEZE: A tool for the calculation of the disordered solvent contribution to the calculated structure factors. Acta Cryst. 2015, C71, 9-18. [CrossRef]

49. Van Dun, S.; Ottmann, C.; Milroy, L.C.; Brunsveld, L. Supramolecular Chemistry Targeting Proteins. J. Am. Chem. Soc. 2017, 139, 13960-13968. [CrossRef] [PubMed]

50. Menozzi, E.; Busi, M.; Ramingo, R.; Campagnolo, M.; Geremia, S.; Dalcanale, E. Design and Self-Assembly of Ditopic and Tetratopic Cavitand Complexes. Chem. Eur. J. 2005, 11, 3136-3148. [CrossRef]

51. Busi, M.; Cantadori, B.; Boccini, F.; De Zorzi, R.; Geremia, S.; Dalcanale, E. Molecular Recognition with Ditopic Cavitand Re Complexes. Eur. J. Org. Chem. 2011, 2011, 2629-2642. [CrossRef]

Sample Availability: Samples of the compound Tiiii $\left[\mathrm{H}, \mathrm{CH}_{3}, \mathrm{CH}_{3}\right]$ is available from the authors. 